\title{
Frequency of Repeated Courses its Relation to Persistence and Performance in Lebanon's Higher Education
}

\author{
Ramzi Nasser (Corresponding author) \\ Center of Educational Development and Research \\ Qatar University, POBOX 2713 Doha, Qatar \\ Tel: 9-746-605-7952Ｅ-mail: ramzin@qu.edu.qa \\ Diane Nauffal \\ Institutional Research and Assessment \\ Lebanese American University, P.O.Box: 13-5053, Beirut: 1102 2801, Lebanon \\ Tel: 961-368-9050Ｅ-mail: Diane.nauffal@lau.edu.lb
}

Received: November 10, 2011 Accepted: November 17, $2011 \quad$ Published: March 1, 2012

doi:10.5539/hes.v2n1p20

URL: http://dx.doi.org/10.5539/hes.v2n1p20

This research project was partially supported by a Qatar University Internal Grant (QUDF-EDU-10 114)

\begin{abstract}
This study assesses the relationship between the frequency of repeating courses and students' performance in college. The study uses cohort data from academic years 2000/2001, 2001/2002, 2002/2003 and 2003/2004. We compared those who had repeated one, two and three courses on GPA and whether a relation exists of those who graduated/did not graduate. The analysis was extended to address the difference of those who repeated once, twice and three times; one, two and three courses respectively. The most common type of repeaters were those students who repeated one course once. These students were more prone to graduate at higher rates and perform better than those who repeated one course twice. In addition, students who failed and repeated courses generally performed better than students who failed but did not repeat the courses. The results from this study indicate that the university should do away with excessive repetitions.
\end{abstract}

Keywords: Repeating courses, Courses repeated more than once, Repeating the same course once twice three times, Higher education, Lebanon

\section{Introduction}

In higher education, students are said to repeat a course if they attempt the course more than once and earn a grade for the course after each attempt. Students repeat university courses to raise their grade point average (GPA) or because they fail or withdraw from courses before the end of the academic term. Casas \& Meaghanm's (1996) high-profile study identifies two benefits of repeating courses. First, it gives students the opportunity to learn material they were not able to understand or material they missed during their first attempt. Second, students have the chance to remediate their learning and improve their grades. (Peterson, Degracie \& Ayabe, 1987; Shephard \& Smith, 1989; 1990; Alexander, Entwistle \& Dawber, 1994; Torres, 1995).

In a meta-analysis of several hundred studies, Jimerson (2001) found an inverse relationship between course repetition and students' academic performance. Students who repeated courses did not perform as well as those who did not. A similar inverse relationship between students' academic performance and course repetition was found in studies in different parts of the world. In Uganda, for instance, school repetition is associated with school persistence (Africa News, 2008). In Australia, repetition has been associated with greater school funding: the greater the number of students that repeats courses, the more funding schools receive to provide remedial lessons for lower achievers (Masanauskas, 2009). Beekhoven, De jong \& Van hou (2003) expanded their study to relate students' performance at the pre-baccalaureate level to that at the baccalaureate level. They found that students who repeat courses at the pre-baccalaureate level take longer to graduate from school and tend not to perform as well in higher education as those who do not repeat courses. 
There have been few studies in recent years that compare students who repeat courses and non-repeaters in higher education. Moreover, almost no studies in higher education have addressed repetition in relation to retention and graduation. A study on the effectiveness of repeating courses on academic performance showed that students who repeat college courses were prone to face difficulties and receive higher grades than those who did not repeat. Likewise, in higher education, repeated courses by students who pass through the system tinges other students whether to repeat or not. Other repeat to fulfill requirements as in seeking admission to universities or dodging university probation or academic expulsion (Counts, DeClue \& Pace, 1974). Students are generally encouraged to repeat courses when there is no risk associated with repeating courses (Casas \& Meaghanm, 1996).

Course repetition at the university level is extensive in North America. For instance, in Florida, 1 in 5 university students tend to repeat a course at school level. Likewise in Ontario, Canada, $20 \%$ of secondary school graduates repeat courses (Casas \& Meaghanm, 1996). Most repeated courses were developmental courses, i.e., remedial-level courses (Adelman, 1999; Hom, 2007) and, specifically, courses in English (Turner, 2005; Hom, 2007). A report produced by Mery (1995) for the City College of San Francisco showed that international students had the highest repetition rate of $88.63 \%$ in their English as a Second Language courses than the college's overall credit course completion of $80.5 \%$ having the highest level course repetition. A study conducted by Turner (2005) in nursing schools found that the more times a student repeated a nursing course, the higher the failure rate was on the National Council Licensure Examination for Registered Nurses. Morrison and No (2007) showed there were no statistically significant differences with respect to learning styles and learning strategies between repeaters and non-repeaters. In a college case study, Fenton (2002) found that there were no differences between those who repeated and those who did not repeat courses. In addition, she found that those who repeated were more likely to persist in a non-degree status than those who did not repeat.

By institutional practices allowing course repeats puts into question how much is gained by allowing such practices. For instance, repeating a course costs as much as holding a "university place" for a qualified person. Allowing students to repeat generally backlogs seats for courses and disrupts the flow of students in and out of a university. According to Casas \& Meaghanm (1996), repeating courses in specific programs raises equity and equal opportunity issues when there is limited access to such courses or programs. In addition, course repetition policy differs from one institution to another; how these repeats are reported in student grade reports and transcripts also differs. It becomes clearly evident that policy and operative aspects that higher education institutions must address in face repeating course analysis.

Although policy related to repeating courses is generally unique to each institution, many universities allow students to repeat courses more than once. The expectation is that the more times a student repeats a course, the lower the failure rate is in that course. The question is whether allowing students to continue to repeat courses when they fail more than once is a permanent solution or merely a panacea to a fundamental problem of underachievement in higher education.

While a number of studies have shown the deleterious effect of repeating courses, no study has shown the relationship between repeating courses more than once and student retention and performance. If repeaters have low grades, it is not clear how much additional learning is gained by repeating courses one, two, or three times. Second, from an institutional research perspective, success at university is generally measured in student persistence and graduation (Wiessman, 1999; and Hagedorn, Maxwell, Chen, Cypers, and Moon, 2002). Hagedorn et al. pointedly argue that the course completion ratio is a more accurate indicator of university students' academic success than other measures of retention and persistence. Generally, understanding formatively the value of repeating courses may help policy makers develop policy on repetition to address the cost, benefits and possible optimal level of repetition.

This study assesses the effect of repeating courses on students' performance in a private university in Lebanon. This study questions whether those who repeat a course fair better than those who do not. This study addresses whether the difference in performance among students who repeat courses is reflected in grade point average (GPA) or whether they graduated/did not graduate from the university. In addition, studying the relation of those who repeated courses and those who did not repeat a course in relation to whether students graduated or not. We used a large sample of students from a comparatively large private university in Lebanon.

This study uses a number of cohort groups and subgroups obtained from the university student enrollment database. In the first analysis, we describe the number of students who repeated one, two, three and four repetitions and three. Second, we determined whether the number of repeated courses, once, twice or three times showed difference on GPA. Third, whether repetition was is related to student graduation. Fourth, we compare those who repeated courses with those who did not repeat a course to determine whether repeating courses has a direct effect on subsequent 
course performance and general academic performance. Finally, the average grades of repeated courses will be crossed with GPA.

\section{Method}

Each semester, to avoid probation or academic suspension, students who earn a failing grade in a course can take the course again at this private university. All records of courses taken are registered in the student banner system; they are also stored in the student registrar system. Data was mined to obtain all repeaters, courses repeated, number of repeats and whether students repeated one, two or three times. In addition, the following information was collected for each student: a record of course repetition, grades for each course, whether the course was repeated or not, semester GPA, cumulative GPA at graduation, and whether students graduated or dropped out. The basic design was a crossed design with the number of times a course was repeated (once, twice or thrice) on GPA and whether students graduated or not.

We used data of cohort groups and subgroups obtained from the student registrar database for the academic years 2000 to 2003. The selection of data for the consecutive academic years 2000/2001 to 2003/2004 allowed us to see if the students graduated from the traditional 4-year programs in 2010. In the first analysis, we sought to determine whether the number of students who repeated a course once, twice, or thrice differed. Second, we analyzed the difference of those who repeated one course, once, twice, or three times, the same difference-analysis was performed for those who repeated two and three courses; once, twice and thrice. Third, we analyzed whether the number of repeated courses was related to students who graduated or left the university. Fourth, we determined whether a relation existed those who failed a course but did not repeat with those who failed but repeated in relation to graduation.

\subsection{Statistical Analysis}

First, a frequency distribution of repeated courses was performed to identify the locus of course repetition. A second analysis included a paired sample t-test between those who had taken the course one, two, and three times. For instance, those who took the course once were compared to those who took the course twice. The third analysis was an analysis of variance (ANOVA) to determine whether the number of courses repeated (one, two, or three) impacted the cumulative grade point average. This analysis was repeated for those who repeated courses two and three times. In the fourth analysis, we crossed those who had repeated courses with graduation (graduated/did not graduate). Because students could repeat different courses more than once, we separated the analyses into those who repeated one, two or and three courses one time, those who repeated one, two, and three courses two times and those who repeated one, two, or three courses three times. The fourth analysis required a Chi-square analysis performed sequentially for those who repeated once, twice and three times a number of courses. The fifth and last analysis included three binary logistic regressions. The first logistic regression included those who failed and repeated courses once; the second included those who failed and repeated courses twice; and the third included those who failed and repeated courses three times.

\section{Results}

Table 1 shows the frequency of course repetition. The highest frequency percentage was for students who repeated a course one time $(17.9 \%)$.

\section{Insert Table 1 Here}

The second analysis addressed the difference between students who had taken a course one, two or three times. We compared the course grade at each time the course was taken. Students who took the course one time performed better in the course than those students who took the course two or three times. An independent paired t-test showed that students who took courses once $(\mathrm{M}=1.81, \mathrm{SD}=0.79)$ performed significantly higher $(\mathrm{t}(\mathrm{df}=737)=2.44, \mathrm{p}=0.015)$ than those who took courses twice $(\mathrm{M}=1.71, \mathrm{SD}=0.04)$. No difference in performance appeared $(\mathrm{t}(\mathrm{df}=149)=0.26$, $\mathrm{p}=0.80)$ between those who took courses two times $(\mathrm{M}=1.52, \mathrm{SD}=1.02)$ and those who took courses three times $(\mathrm{M}=1.22, \mathrm{SD}=0.10)$. Hence, students who take the course once tend to perform better than those who repeat the courses two or three times. In the second analysis, we compared the GPA of students who had repeated one course one, two, and three times. The same analysis was conducted for two and three courses that were repeated.

Analysis of variance (ANOVA) was used to determine whether student GPA differs with the number of courses repeated. There were significant differences in GPA according to the number of courses repeated. We ran three separate ANOVAs to determine the effect on GPA when one, two and three courses were repeated once twice and three times. The same analysis was repeated for courses that were repeated two and three times; at each analysis comparisons were made between the number of courses taken; one, two or three courses. The findings showed that overall, there were significant differences among those who had one repetition $(\mathrm{F}(3,923)=4.13, \mathrm{p}=0.006)$. The 
Bonferroni post-hoc test showed that there was a significant difference between students who made one repetition of one course $(M=2.29, S D=.77)$ compared to those who repeated three courses one time $(M=2.06, S D=0.60)$. There was no significant difference in the GPA of students who repeated one, two or three courses twice $(F(3,527)=1.92$, $\mathrm{p}=0.13)$. There was a significant difference $(\mathrm{F}(1,177)=7.05, \mathrm{p}=0.009)$ between those who repeated one course $(\mathrm{M}=1.98, \mathrm{SD}=0.56)$ and two courses $(\mathrm{M}=1.65, \mathrm{SD}=0.69)$ three times. Generally, those who repeated one course once had a higher cumulative GPA than those who repeated two or three courses. These results are generalizable to courses repeated two and three times.

In the fourth analysis, we crossed the graduation variable (graduated/did not graduate) with repetition. We nested the number of courses within course repetitions. We ran three separate Chi-square analysis for one, two and three repetitions of one, two and three courses, respectively. A Chi-square test was used to determine the relation between graduation and course repetition. In the first analysis, we found a non-significant Chi-Square statistic $\left(\chi^{2}(1578,2)=3.37, p=0.19\right)$ which showed no relationship between graduating or not graduating and repeating one, two or three courses one time. However, a significant relation was found between those who graduated and those who did not graduate when students repeated a course two times $\left(\chi^{2}(737,2)=14.32, p=0.001\right)$ and three times $\left(\chi^{2}(226,2)=17.35, \mathrm{p}=0.000\right)$. Those students who repeated one course two times were more likely to graduate than not graduate. Those students who repeated two and three courses two times were more likely not to graduate than graduate. Students who had three repetitions of one course were more likely not to graduate than graduate; students who repeated two courses three times as well as those who repeated three courses three times were less likely to graduate. These findings suggest that students who repeated the same course one, two or three times were more likely to graduate than not graduate. In contrast, students who repeated two or three courses two or three times were more likely not to graduate than graduate.

Insert Table 2 Here

In the final analysis, we ran three binary logistic regressions. The first logistic regression analysis performed was of those who failed but repeated courses once; the second regression for those who failed but repeated courses twice, and those who failed but repeated courses three times. Each of the logistic regression included two independent variable those that failed but repeated, and a second variable of students who failed but did not repeat. The dependent variable included students who graduated ("1") or did not graduate ("0"). The findings indicate that those who failed but did not repeat was inversely related to graduation, with a greater negative beta coefficient compared to those who repeated courses one or two times (see Table 3). However, repeating courses three times had a greater and significant negative predictor value compared to failing and not repeating. Thus, not repeating courses can predict graduation negatively (binary sense - no graduation).

\section{Insert Table 3 Here}

\section{Discussion}

The study is significant for two basic reasons. First, if repeaters are low achieving in college, it is legitimate to determine whether repeating a course improves their performance. Second, if students do repeat what could be the level of repetition (i.e, one, two or three repetitions) that could retain students (graduate) or indicate the some level performance.

The outcome of repeated courses showed that there were differences in the number of repeated courses. In terms of those who repeated the course once they had a higher percentage than those students who repeated courses twice or three times. Even those who repeated the course once, one time had higher GPA than those who repeated the course once repeating two or three courses. At the same level of importance this research is that college students who fail courses and repeat just one course one time are more likely to graduate than not graduate and, thus, perform better than students who repeat one course two or three times. In other words, students who repeat the same course twice or three times will generally not improve their academic performance drastically compared to those who repeat only once.

Previous studies show little performance difference between those who repeat courses and those who do not (Jackson, 1975; Fenton, 2002). Restricted range (i.e., comparison of one, two and three times) may be one reason these studies did not find a strong relationship between repeating courses and performance because the population of students in a particular cohort was not sampled. Our findings suggest that there is a significant positive relationship between students who fail and repeat the course once. An inverse relationship average found between students who failed and did not repeat and graduation. Also, failing and then repeating courses two or three times was negatively related to graduation. Students who repeated one course one time graduated at proportionally higher rates than those who repeated one course, two, or three times. 
The findings of this study suggest that the policy of permitting students to repeat courses needs to be further restricted. Generally, repeating a course once has a larger effect on academic success than repeating a course two or three times. Thus, allowing students to repeat more than once may not be the right formula to encourage students to persist. It may be appropriate to regulate the conditions under which repetition is allowed because repeaters in competitive programs might be holding up admission for other students, (Casas \& Meaghanm, 1996). For example, it may be wise to discourage students who achieve higher-than-average grades from repeating a course in order to raise their GPA.

Repeating regulations should be based on the chain of demand and supply of specific academic programs. Where there is a high demand for certain programs and greater value being placed on such programs, regularity restrictions must be in place to address the and equity considerations rather than financial ones. Policies that allow students to repeat courses more than twice may seem at first financially attractive; however, in the long-run, it might do more harm to persistence to the successful completion of a program. One possible solution is to allow repetition in the summer, which takes away the pressure to make room in course for new students. As Pfiefer (1985) found in her master's thesis, student success in repeated courses taken during the summer was greater than success in courses repeated during the regular semester and one possibility that universities could opt as repetition policy.

The general result of repeating courses suggests that monitoring course repetition by institutional and policy research offices is greatly needed. Further, programs and courses should be analyzed to determine which courses have the highest rate of repetition in order to improve programs and help students to progress to successful completion.

This study showed that the GPA of students who repeat courses more than once does not improve as a result of repetition. Also, the study findings showed that students who repeat courses more than once are less likely to graduate. The study results suggest that universities should reconsider their course repetition policies because allowing students to repeat courses more than once may be delaying the admission of potentially high-achieving students.

\section{Conclusion}

The results of this study are significant to the extent that they address issues of retention and persistence relative to the strategic development of the university. This study is illuminating given that few studies have examined: the effect of course repetition on the performance of university student. The irregularities that may occur in university programs, specifically among students who repeat courses. One important finding of this study is that students who repeat one course are more likely to persist than those who repeat more than one course more than one time. This study provides a foundation for the development of a standard analytical approach for evaluating the effect of course repetition on student performance at the university level.

\section{References}

Adelman, C. (1999). The new college course map and transcript files: Changes in course-taking and achievement, 1972-1994. $2^{\text {nd }}$ ed. Washington, DC: National Center on Postsecondary Education, Libraries, and Lifelong Learning.

Alexander, K., Entwistle, D. \& Dawber, S. L. (1994). On the success of failure: a reassessment of the effects of retention in the primary grades. New York: Cambridge University Press.

Beekhoven, S., De jong, U. \& Van hout, H. (2003). Different courses, different students, same results? An examination of differences in study progress of students in different courses. Higher Education, 46, 37-59. http://dx.doi.org/10.1023/A:1024414529666

Casas, F., \& Meaghanm, D. (1996). A study of repeated courses among secondary students in Ontario. Journal of Educational Research, 90(2), 116-127. http://dx.doi.org/10.1080/00220671.1996.9944453

Counts, G., DeClue, M., \& Pace, R. (1974). Grades earned in repeated courses. Journal of Experimental Education, 42(3), 11-16.

Fenton, K. (2002, June). Strategy faced with failure: Persistence and degree attainment of course repeaters versus non-repeaters. Paper presented at the Association of Institutional Research, Toronto Ontario. (ERIC Document \# ED473114)

Hagedorn, L.S., Maxwell, W. B., Cypers, S., Moon, H. S., Lester, J. (2003). Courseshopping in the urban community colleges: An analysis of student drop and add activities. Los Angeles, CA: Center for Higher Education Policy Analysis. (ERIC Reproduction Service Document No. ED477196)

Hom, E. (2007). The academic goals, course repetition, and completion ratios of Asian and Latin American international students in urban community colleges. Doctoral Dissertation University of Southern California. 
Jackson, G. B. (1975). The research evidence on the effects of grade retention, Review of Educational Research, 45(4), 613-635.

Jimerson, S. R. (2001). A synthesis of grade retention research: looking backward and moving forward, California School Psychologist, 6, 47-59. [Online] Available: http://education.ucsb.edu/school-psychology/CSP-Journal/PDF/CSP_2001(volume_6).pdf (September, $7^{\text {th }}$ 2011)

Masanauskas, J. (2009, March). Prep kids our top repeaters are students held back to top up funding? Education Reports, 25

Mery, P. M. (1999). School profiles: School enrollments by department, fall terms1994-1998. San Francisco, CA: City College of San Francisco Office of Institutional Development, Research, and Planning. (ERIC Reproduction Service Document No. ED443503).

Morrison, K., \& No, A. (2007). Does repeating a year improve performance? The case of teaching English. Educational Studies, 33(3), 353-371. http://dx.doi.org/10.1080/03055690701423333

Peterson, S. E., Degracie, J. S. \& Ayabe, C. R. (1987). A longitudinal study of the effects of retention/promotion on academic achievement, American Educational Research Journal, 24(1), 107-118.

Pfeifer, J. (1985). Student accountability and course repetition. What works best? Master's Thesis, Southern Oregon State College.

Shephard, L. S. \& Smith, M. L. (1989). Flunking grades: research and policies on retention. London: Falmer.

Shephard, L. S. \& Smith, M. L. (1990). Synthesis of research on grade retention. Educational Leadership, 47, 84-88.

Torres, R. M. (1995). Repetition: a major obstacle to education for all, Education News, 5(2), 5-10.

Turner, L. (2005). faculty and program predictors of pass rates of graduates of Nursing Programs in West Virginia on the National Council Licensure Examination for Registered Nurses 1991 to 2000. Doctoral Dissertation, Marshall University.

Weissman, C. (1999). Time-to-degree and credits-to-degree of baccalaureate degree graduates. Doctoral Dissertation, University Dakota.

Table 1. Course frequency repetitions

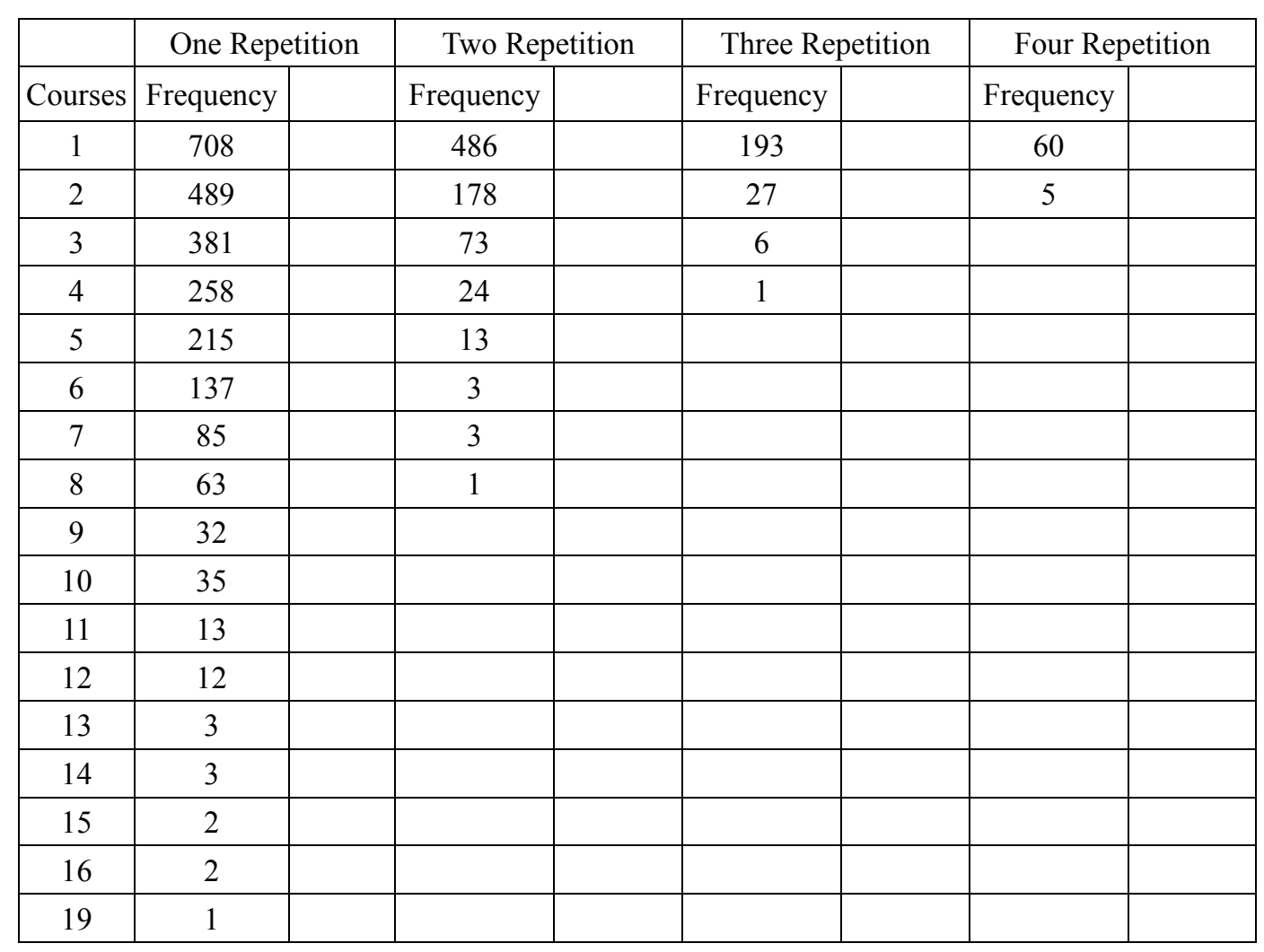


Table 2. Percentages of graduates and did not graduate crossed by repetition

\begin{tabular}{|c|c|c|c|c|c|c|c|c|c|c|c|c|}
\hline & \multicolumn{4}{|c|}{ One Repetition } & \multicolumn{4}{|c|}{ Two Repetitions } & \multicolumn{4}{|c|}{ Three Repetitions } \\
\hline & $\begin{array}{c}1 \\
\text { course }\end{array}$ & $\begin{array}{c}2 \\
\text { courses }\end{array}$ & $\begin{array}{c}3 \\
\text { courses }\end{array}$ & Total & $\begin{array}{c}1 \\
\text { course }\end{array}$ & $\begin{array}{c}2 \\
\text { courses }\end{array}$ & $\begin{array}{c}3 \\
\text { courses }\end{array}$ & Total & $\begin{array}{c}1 \\
\text { course }\end{array}$ & $\begin{array}{c}2 \\
\text { courses }\end{array}$ & \begin{tabular}{|c|}
3 \\
courses \\
\end{tabular} & Total \\
\hline $\begin{array}{l}\text { Did not } \\
\text { Graduate }\end{array}$ & 155 & 127 & 98 & 380 & 190 & 83 & 45 & 190 & 89 & 24 & 3 & 116 \\
\hline $\begin{array}{l}\% \text { within } \\
\text { row }\end{array}$ & $40.8 \%$ & $33.4 \%$ & $25.8 \%$ & $100.0 \%$ & $59.7 \%$ & $26.1 \%$ & $14.2 \%$ & $59.7 \%$ & $76.7 \%$ & $20.7 \%$ & $2.6 \%$ & $\begin{array}{c}100.0 \\
\%\end{array}$ \\
\hline $\begin{array}{l}\% \text { within } \\
\text { Column }\end{array}$ & $21.9 \%$ & $26.0 \%$ & $25.7 \%$ & $24.1 \%$ & $39.1 \%$ & $46.6 \%$ & $61.6 \%$ & $39.1 \%$ & $46.1 \%$ & $88.9 \%$ & $50.0 \%$ & $\begin{array}{c}51.3 \\
\%\end{array}$ \\
\hline Graduated & 553 & 362 & 283 & 1198 & 296 & 95 & 28 & 296 & 104 & 3 & 3 & 110 \\
\hline $\begin{array}{l}\% \text { within } \\
\text { row }\end{array}$ & $46.2 \%$ & $30.2 \%$ & $23.6 \%$ & $100.0 \%$ & $70.6 \%$ & $22.7 \%$ & $6.7 \%$ & $70.6 \%$ & $94.5 \%$ & $2.7 \%$ & $2.7 \%$ & $\begin{array}{c}100.0 \\
\%\end{array}$ \\
\hline $\begin{array}{l}\% \text { within } \\
\text { Column }\end{array}$ & $78.1 \%$ & $74.0 \%$ & $74.3 \%$ & $75.9 \%$ & $60.9 \%$ & $53.4 \%$ & $38.4 \%$ & $60.9 \%$ & $53.9 \%$ & $11.1 \%$ & $50.0 \%$ & $\begin{array}{c}48.7 \\
\% \\
\end{array}$ \\
\hline $\begin{array}{c}\text { Total } \\
\text { Count } \\
\end{array}$ & 708 & 489 & 381 & 1578 & 486 & 178 & 73 & 486 & 193 & 27 & 6 & 226 \\
\hline $\begin{array}{l}\% \text { within } \\
\text { row }\end{array}$ & $44.9 \%$ & $31.0 \%$ & $24.1 \%$ & $100.0 \%$ & $65.9 \%$ & $24.2 \%$ & $9.9 \%$ & $65.9 \%$ & $85.4 \%$ & $11.9 \%$ & $2.7 \%$ & $\begin{array}{c}100.0 \\
\%\end{array}$ \\
\hline $\begin{array}{l}\% \text { within } \\
\text { Column }\end{array}$ & $100.0 \%$ & $100.0 \%$ & $100.0 \%$ & $100.0 \%$ & $100.0 \%$ & $100.0 \%$ & $100.0 \%$ & $100.0 \%$ & $100.0 \%$ & $100.0 \%$ & $100.0 \%$ & $\begin{array}{c}100.0 \\
\%\end{array}$ \\
\hline
\end{tabular}

Table 3. Binary logistic regression for failed but repeated and not repeated courses on graduation

\begin{tabular}{|l|r|r|r|c|c|c|}
\hline & \multicolumn{1}{|c|}{ B } & \multicolumn{1}{c|}{ S.E. } & \multicolumn{1}{c|}{ Wald } & \multicolumn{1}{c|}{ Df } & \multicolumn{1}{c|}{ Sig. } & Exp(B) \\
\hline Failed but not repeated & -.910 & .129 & 49.564 & 1 & .000 & .403 \\
\hline Repeated courses once & .232 & .121 & 3.684 & 1 & .055 & 1.261 \\
\hline Constant & 1.988 & .317 & 39.408 & 1 & .000 & 7.304 \\
\hline Failed but not repeated & -.707 & .147 & 23.116 & 1 & .000 & .493 \\
\hline Repeated courses twice & -.389 & .172 & 5.096 & 1 & .024 & .678 \\
\hline Constant & \multicolumn{1}{|c|}{2.273} & .397 & 32.732 & 1 & .000 & 9.712 \\
\hline Failed but not repeated & -.808 & .273 & 8.750 & 1 & .003 & .446 \\
\hline Repeated courses thrice & -2.393 & .820 & 8.513 & 1 & .004 & .091 \\
\hline Constant & 4.562 & 1.07 & 17.988 & 1 & .000 & 95.795 \\
\hline
\end{tabular}

